\title{
Consequences of Ineffective Policies and a Risk of Default in Russia and the Eurozone
}

\author{
Prof. Dr. Viktor Barhatov (Chelyabinsk State University, Russia) \\ Assoc. Prof. Dr. Yuner Kapkaev (Chelyabinsk State University, Russia) \\ Sergei Poliduts (Chelyabinsk State University, Russia)
}

\begin{abstract}
The present paper investigates the nature and essence of the state's debt policy and identifies patterns that contribute to the default. It assesses the status and the effectiveness of public debt management both in Russia and several European countries. The paper suggests a number of specific measures and instruments of economic, legal and administrative measures aimed at improving the efficiency of public debt management and minimizing the risk of default. A methodological basis of the study that has served as a dialectical approach, reveals a possibility of studying debt management policies and a study group's practices of dealing with a state debt. A systematic approach to the subject of the study has revealed the existing connections and interdependence between the implementation of debt policy and the process of public debt management. The paper uses some data from the Eurostat and the Rosstat, allowing the complex to investigate the dynamics of basic indicators of the government's debt in Russia and the Eurozone. Based on some determined patterns, the paper identifies the main positive and negative trends of public debt management in the surveyed countries. The assessment of key indicators of the current state of a debt, has revealed a number of contradictions that have a negative impact on the debt burden, which in its turn increases the likelihood of a default. The basic steps to improve the efficiency of public debt management relate to legal aspects and financial planning in conjunction with a skillful use of an administrative resource.
\end{abstract}

\section{Introduction}

Some lessons have been drawn from the current financial crisis which continues to shake the financial structure of the world in the recent past. The first and the most valuable of them is an understanding of the fact that all financial assets have risks.

Even bonds of many sovereigns are absolutely fairly called into question. Although they are often considered to be "risk-free", because the state can collect taxes from citizens, but one's logic proves the opposite, that is to say, there is nothing risk-free in real life. Such a conclusion may be drawn even after the most superficial acquaintance with a monetary history or while watching events of the past years, which is especially useful and instructive. Undoubtedly, sovereign bonds are risky.

Actually, they are associated with three of such risks. Each of them should be seriously considered and analysed before buying bonds of any country.

Firstly, there is a currency risk. There are two types of such a risk. The first one is an inflation which destroys the purchasing power of currencies since the governments rejected the gold standard many years ago. It is especially a real risk in present conditions when interventions of the Central Bank create artificially underestimated interest rates, and therefore the profitability of bonds can hardly fully neutralise a loss of the purchasing power of currency in which a bond is denominated. Another risk are floating currency quotations. Falling quotations will reduce the cost of the bonds denominated in a foreign currency. For example, any investor from the Eurozone, who owns some bonds denominated in British pounds, suffered losses when the pound sharply fell in price against the euro a few years ago.

Secondly, there is risk associated with interest rates. Although the central banks are actively interfering with credit markets in order to hold interest rates at a low level, the rates will inevitably grow up again. Growing interest rates will cause a fall in prices of bonds. They will fall down to such a level at which the profitability of coupons of bonds will be always equal to a current interest rate.

Thirdly, there is a counteragency risk. The most devastating of all risks is a risk of a default. A country will pay off according to its obligations only if it possesses financial opportunities and a desire to pay. In this regard, investors have drawn a lesson from the latest events, consisting in that many countries are no more capable of servicing their debts even if they wished.

Despite all the latest events, many owners of bonds still believe that they will be able to receive a favorable ratio of a risk to profitability, having bought some state bonds. Probably, in the past things looked like this, but today the majority of governments are hampered with debts and are on the edge of an abyss. It does not make sense any more to expect that a state bond can be bought and held before a maturity date terminates. They became a trade tool which is sold and bought as a commodity resource for the purpose of getting a profit on price fluctuations. It demands unique skills, therefore it is reasonable to leave sovereign bonds to professional traders and speculators. 
Many promises made by politicians will be broken because the countries live beyond their means. Including insincere words that state debts will be always serviced. It is obvious that many states worldwide are aground and in such a situation sovereign bonds, without any doubt, bear the risks.

\section{Methodology and Results}

An analysis is presented in the present article regarding the information about the world's state risk of bankruptcy after events that have just recently occurred and that are connected with changes in governmental and economic policy, with an introduction or a failure of rigid budgetary reductions.

A country's risk of bankruptcy/rescue represents an existing possibility of bankruptcy and subsequent predefault rescue (in the presence of an opportunity). The current level of the gain in the gross domestic product of each of the countries, the total amount of the state debt, governmental and bank debts, a budget deficit, the total amount of an external debt and interest rates of the market of state bonds are taken into account, and in addition, an ability of liquidating a debt by devaluation and inflation is considered, which is impossible for the majority of members of the Eurozone.

Mechanisms of a rescue, introduced at present by the Eurozone, are capable only to delay final bankruptcy; in the event of Greece and Ireland it means financing of deficiencies within three years and debt restructuring, which, as a result, only increases the debt burden of the saved countries and, thus, increases the pressure of indebtedness upon economy as the percentage share of a debt as part of the gross domestic product grows every year, until the time when a country has to re-structure its debts again.

One of the major drivers of default risk generally accepted as significant by several important researches is the country's budget balance in relation to GDP. Another important factor in the literature and also mentioned in the Maastricht Treaty is the total government debt to GDP. A higher indebtedness level raises per se the default risk. In consequence, the country has to spend more funds for debt servicing. In addition to the total outstanding debt, the interest rate costs may also trigger the default risks, as higher interest values are positively correlated to the country's collapse likelihood. Hence, the debt service becomes more expensive and increases the debt burden for the entire economy. Table 1 presents the main determinants of default risk in the Eurozone; this considerable threat on several EMU countries is crucial as it has led to financial turmoil in the region, imposes high costs for all members and questions the very future existence of the EZ.

\begin{tabular}{|l|l|c|c|}
\hline \multicolumn{1}{|c|}{ Variable } & \multicolumn{1}{|c|}{ Source } & $\begin{array}{c}\text { Probability of } \\
\text { inclusion }\end{array}$ & $\begin{array}{c}\text { Direction of } \\
\text { influence }\end{array}$ \\
\hline Budget balance to GDP & Economist Intelligence Unit & 82.4 & - \\
\hline $\begin{array}{l}\text { Total government debt to } \\
\text { GDP growth }\end{array}$ & IMF World Economic Outlook & 76.4 & + \\
\hline Average interest rate & $\begin{array}{l}\text { Annual Macroeconomic Database of the } \\
\text { European Commission }\end{array}$ & 4.6 & - \\
\hline GDP growth & OECD Economic Outlook & 12.5 & + \\
\hline Imports growth & IMF International Financial Statistics & 30.8 & - \\
\hline Exports growth & IMF International Financial Statistics & 11.1 & - \\
\hline Terms of Trade growth & Economist Intelligence Unit & 83.7 & - \\
\hline Inflation & IMF World Economic Outlook & 8.2 & - \\
\hline Inflation variation & $\begin{array}{l}\text { Own calculations based on IMF World } \\
\text { Economic Outlook }\end{array}$ & 5.6 & + \\
\hline Capital formation & $\begin{array}{l}\text { Annual Macroeconomic Database of the } \\
\text { European Commission }\end{array}$ & & - \\
\hline US interest rate & DATASTREAM & 15.4 & + \\
\hline
\end{tabular}

Table 1. Determinants of default risk in the Eurozone Source: The economic world

The risk of a propagation, in case of a default, of debt commitments is measured by the world's influence of bankruptcy of each country in a percentage of $0 \%$ to $100 \%$. The USA possess a 100 percent risk: based on the fact of how bankruptcy of this country will affect the world's financial system, it is meant that this system and, probably, the world's economy will collapse with probability of $100 \%$.

For example, the bankruptcy of Iceland in October 2008 had no essential effect of infection because of its small economic scale and coverage of the external debt, while such countries as Ireland, are characterised by a much bigger factor of infection, therefore the rescue of Ireland by the European Union / the IMF at the rate of 85 billion euros is much less than the expected damage during the propagation of panic and in view of an increase in the risk of a default in other large countries, since contractors of Irish banks and owners of Irish debts will begin to face problems. 
However, a rescue does not completely nullify a risk factor of infection because holders of bonds and counteragents will be as before threatened by a probability of restructuring a debt at some moment in the future, which thus yet escalates to some extent a risk of a default of all other vulnerable countries. A key indicator when determining an effect of infection is the size of economy and the total amount of a debt and promissory notes, including external ones.

A default associated with promissory notes is inevitable in all countries. All countries have a tendency towards a default/debt restructuring. However, the majority of countries declare a default connected with their promissory notes by means of increasing the real rate of inflation. Thus, for most countries a risk of a default is lower because they have an opportunity to avoid it by reducing the cost of their state debt, stealing investors' capital and the purchasing power of employees' salaries by means of inflation.

For example, the Government of Great Britain is printing money which it lends to bankrupt banks at an interest of $0.5 \%$ for the purchase of British governmental bonds at am interest of $3.3 \%$. This is why the profitability of these bonds is lower than that of Spanish and Italian bonds: it permits to prevent an instant default, but is done at the expense of a high inflation. In this respect, a falsified official CPI (Consumer Price Index) makes up 3.2\%, a more obvious Retail Price Index (RPI) is equal to $4.5 \%$, and the level of the real inflation reaches $6 \%$.

A secret default achieved by means of inflation poses a smaller risk of a full default because the higher is a real rate of inflation (to a certain limit) the lower is a relative risk of an obvious default since governments use inflation for the reduction of the level of a debt at the expense of incomes and savings.

Taking into consideration the fact that all currencies are in a state of a constant free fall relatively to each other, indebtedness expressed in foreign currencies is to pose a lesser threat by itself as compared with that expressed in a local currency - as opposed to the opinion of many experts. If one considers a default caused by a debt by means of inflation based on the British example, then one may see that pound-to-dollar quotations have not changed for the last 20 years. However, the next schedule diagram shows that the pound lost more than $40 \%$ of its purchasing power for the same period, proceeding from the evidence of the inflation index (Retail Price Index).

Apart from that, debt denomination in local currency reduces a risk of a default, this is why this risk remains very low in the USA.

On the other side of the debt range of currency devaluation by a real inflation are countries of the Eurozone (PIGIBS), which are locked within the limits of the euro and thus cannot declare a default by means of a real inflation. And even in case of their exit from the currency union they will not be able to solve this problem because their indebtedness is expressed in the euro until it is changed to a new currency, which, in its turn, will lead to an instant enormous devaluation (a panicking effect of a hyperinflation is then possible). Thus, until the countries of PIGIBS remain in the Eurozone, they are only capable of internal devaluation through a reduction of salaries and expenses in order to keep the competitiveness of their economies in comparison with other members of the Eurozone. Although the problem - unlike the opportunity to use inflation for a default associated with a debt expressed in a local currency - consists in that when the economic situation deteriorates a share of indebtedness within the gross domestic product increases, and a risk of a default eventually increases. This is why members of the Eurozone probably will need all new rescues until they declare a default which remains inevitable.

An infection factor is the most important one since countries close to a default, even if they are subsequently rescued, are nevertheless capable of causing a crash of the world's financial system in case their factor of infection reaches such a high level as in Great Britain, France and Germany. Fortunately, there are no signs yet that any of these countries can reach a critical condition close to a default in the next half-year or year so they have time to cope with problems of their budget deficit and bank indebtedness.

Also, despite a widespread opinion about the promissory notes and debts of the USA, there remains a low default level there.

One more important factor should be noted: such countries as Pakistan, Mexico and India bear in themselves a much lesser threat of a default because their external debts are by far smaller, and the sizes of their indebtedness are not so critical as compared with those of members of the Eurozone, this is why the debts of Greece, Ireland and Portugal demand for help, while the above-mentioned countries do not need any rescue. As an initial analysis based on the latest data showed, the world of debt risk has turned upside down, and countries which were considered a few years ago as a high risk zone, now pose a smaller threat, while the low risk zones of the past have become very dangerous.

Portugal along with Belgium and Spain can become candidates for rescue in the nearest time. However, it is possible that after rescuing Spain the help to European bankrupts, PIGIBS countries, will end up, especially if the Eurozone introduces new mechanisms of more ordered partial restructuring of a debt, which is capable of weakening pressure upon the debts of Italy and France and, thus, of reducing the effect of infection. 
Meanwhile, all depositors and investors should take care of the protection of their capitals and savings against a risk of infection of PIGIBS, that is reduce susceptibility to a financial risk in banks of the countries of PIGIBS and make sure that sums of deposits come under compensations.

Mechanisms of an organised partial default/restructuring may serve as solutions of a debt crisis.

The Eurozone stands in need of developing mechanisms of partial restructuring of a debt for the purpose of a prevention of a full default demanding an expensive rescue. The present system of financing bankrupt European banks at an interest of $1 \%$ does not work with the European Central Bank as it is exactly the prime cause of the present crisis of state indebtedness: after the credit crisis of 2008 the European banks received money from European Central Bank and using it bought highly profitable promissory notes of the countries of PIGIBS, which has resulted in the current situation.

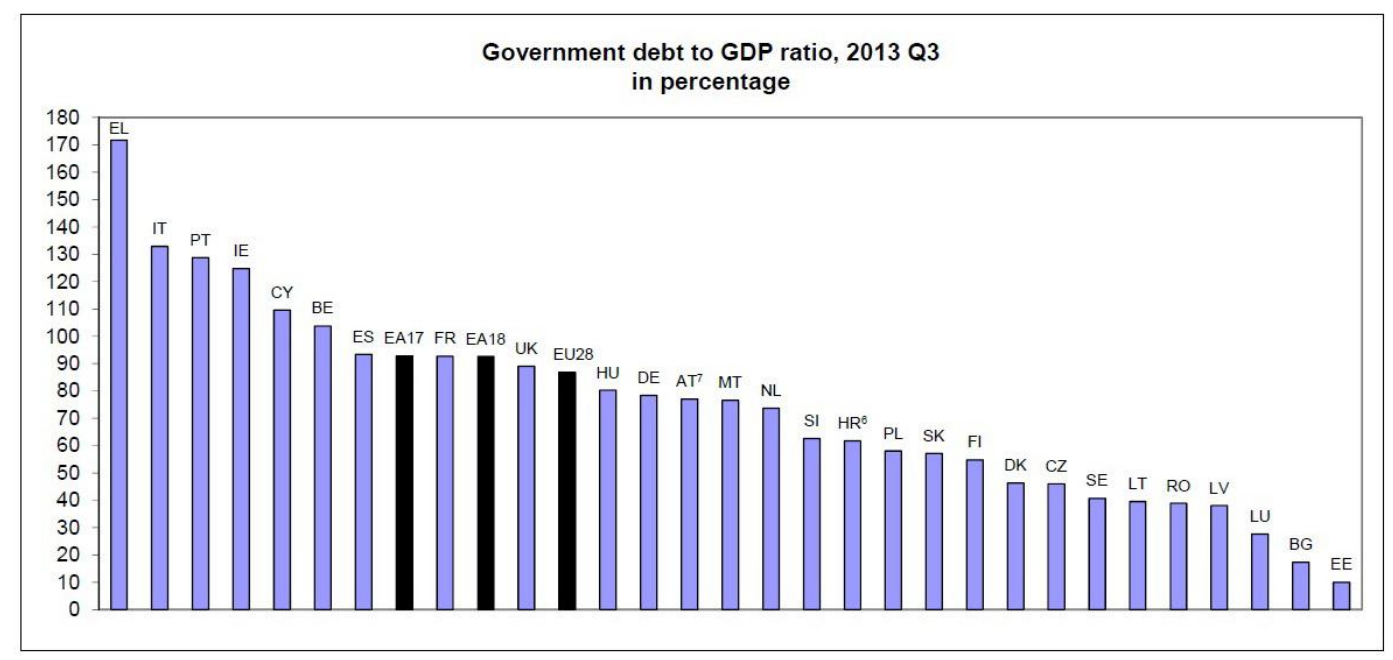

Figure 1. Government debt at the end of the third quarter 2013 by Member State

One of mechanisms of solving this problem is connected with a future issue of bonds of the countries of PIGIBS, which issue is to be carried out on the basis of an assumption that a certain part of these obligations will not be discharged if an issuer government has a high budget deficit by the time of the incoming of a cancellation date. It will lead to a growth of interest rates for the countries of PIGIBS, reflecting a risk of a partial default, as well as create a systematised market for a slow serial debt default, and it will not cause a crisis striking the entire wholesale market of the debts. For example, an issue of ten-year Portuguese bonds with an interest rate of $8 \%$ would be accompanied by a loss of $3 \%$ of this capital at a cancellation date for each $1 \%$, if the budget deficit of Portugal exceeded the permitted $3 \%$, or other similar measures were used.

However, the aforesaid mechanism is applicable only to future debts, so it would take many years for the replacement of the existing debt with a new one inclined to a default, therefore, a mechanism of restructuring the existing debt of the countries of PIGIBS, especially Greece, Ireland and Portugal, is necessary as the level of their indebtedness remains unacceptable. The complexity of the issue consists in a partial default associated with Greek, Irish and Portuguese debts, without a subsequent panic in the debt market of the Eurozone, in which Germany will be the only country capable of attracting investors to bonds.

It is obvious that a mechanism of restructuring the debt of the countries of PIGIBS will imply a transformation of European banks and a separation of state debts from bank indebtedness. This is approximately the way how Ireland should have done with its banks, a responsibility for which had had to be assumed by the European Central Bank, and this would have considerably reduced the debt load of the PIGIBS countries.

In the past week, there appeared some signs that the Eurozone intends to carry out a primary assessment of risks for investors of the bond market. However, it is also clear that no country intends to leave the Eurozone, which fact will probably favour Greece and Portugal in a long-term prospect, because these economies will never be able to compete with Germany head-to-head, and therefore they prepare for a decade of a slowed-down growth in comparison with the Eurozone's industrially developed countries. Also, Germany will not leave the currency union because it is content with the condition of the countries of PIGIBS and the weakening of the euro, which permit it to import goods to the domestic market.

By and large, the bond market needs a reason for purchasing state promissory notes: if the situation remains unclear further on regarding what investors will receive when a cancellation date is due, they will not buy them. Thus, for the debt market of the countries of PIGIBS to function, the Eurozone has to ensure a confidence, otherwise the European Central Bank will be the only buyer of these bonds. 
When predicting default situations in any country seen most attractive probabilistic assessment model of default.

In particular, the most suitable are:

- actuarial methods to calculate certain objective (as opposed to risk neutral) estimate of the probability of default on the basis of some statistical data on defaults;

- methods based on the market value of bonds, shares and financial derivatives, they define a neutral risk assessment of the likelihood of default and the risk premium for the specific issue of securities.

In our case will be considered the most appropriate actuarial methods for estimating the probability of default, exposure involving relevant actuarial estimates of the probability of default. The economic essence of actuarial models is clearly seen on the example of calculating the probability of default. As you know, a key role in detecting signs of default situations play leading ratings agencies.

Calculations presented agencies are taking up a basis when considering the probability of default of the country under study, as are the most objective and relevant real situation in the country as a whole, and in particular the company, depending on which of the objects under investigation. At the same time, we should not forget about the specifics. In particular, the agency «Moody's», in their study emphasizes the political instability of the country, while making a conclusion about the possibility of default situations in the economy. In turn, the agency «Standart \& Poor's» tries to analyze the two main groups of indicators - political and economic. In the study, the country's political indicators Agency explores a combination of factors, and the resulting factor is the willingness to pay its debts, some political will. The study of economic indicators Agency comes from the country's ability to pay its obligations. That's the kind of aggregate function and leads to the calculation of the corresponding numerical value, which is transformed into a letter rating. There are cases when the rating is not assigned, in this case the country's economic situation and the possibility of default is calculated on the basis of their own country's own economic performance.

Consider one example of estimating the probability of default based on the statistics of defaults on bonds, analyzed the data on government bonds of Portugal. To begin with, we define the economic substance of the methodology for assessing the probability of default based on statistics of bond defaults. In this case, the best known in the assessment of the probability of default on the Bonds received studies Altman, 1988-1997. , We should not forget about the methodical operating time Moody's and Standart \& Poor's, which has been previously mentioned in more detail. However, if a closer look at the model offered by the named agencies, their methods had its basis rather extensive statistical data and then expressed in a certain regression formula, which summarized the figures for shares of the issuing companies, announced its default in a given year. At the same time, the agency commit serious errors, analyzing the probability of default as a whole company, and the state, focusing only on a one-year period.

However, practice shows that the age of the bond has a significant impact on how the default company level and at the country level. Moreover, the age of the bond significantly affects the probability of default is the first five years. At this time, the company / issuer state funds exist to service its debt.

In addition, the analysis of the likelihood of default is necessary to examine several datasets on bonds.

In particular, you should pay particular attention to the bonds issued in the current year. In this case, the period of the bonds shall not exceed one year, or taken into account in the analysis of the age of the bond. At the same time it is necessary to consider not all parallel marketable bonds, received a credit rating, to focus only on "direct bonds» with a high yield. So it should be noted that similar studies conducted Altman. But his studies were not of conclusive, definite answer to the question of the country defaulted his model, unfortunately, did not offer.

In assessing the probability of default country, special attention must be paid to the bulk characteristics of the bond market, i.e. is a kind of quantity equal to the ratio of (total nominal value) issues of direct high- Portuguese bonds, which is most likely defaulted to the total volume of this kind of bonds in the market.

Investigating the problem of predicting defaults, some Altman calculated weighted average probability of default, where the weights were the relative amounts of bond issues, which was defaulted. In particular, when using this approach can get a situation where two companies have placed their bonds in the market under the same conditions, will dominate the bonds of the company that issued them to a greater extent. Consequently, the default of another company will not have a significant role in the market and distort the estimates of the probability prediction of adverse factors.

But we should not forget that some major defaults could have a very significant impact on the situation on the market and distort the assessment of the likelihood of default for a given period. It should be noted that the Portuguese government bonds will be a kind of barometer by which you can trace the outlines tendency to default since the stock market in this position bonds can play the role of a "safe haven". Market situation can be very diverse, so expect quite a variant growth in demand for Portuguese papers with further sharp drop in bond prices that will be directly connected with the outflow of capital in more liquid and reliable security. In this case, much will depend on the parity of the capital invested in a single Eurobond, and gold prices. 
But, despite all the speculation, should still provide a general formula for determining the probability of default.

Marginal probability of default MMR (marginal mortality rate) during the t- th period since the release of bonds in circulation is given by

$$
\text { MMRt }=\frac{\text { The cost of bonds for which defaulted in year } t}{\text { Cumulative volume bonds at the beginning of year } t}
$$

The marginal probability of default expresses a statistical evaluation of the probability of default on bonds with a certain credit rating during the $t$ - th year of the date of the paper in circulation. This figure can be expected for several years.

The most interesting and probability value indicative of probability of survival and survival over a certain extended period of time T. Thus, the probability of survival represented by some value SR, unreachable, but tending to $100 \%$. Therefore, the formula is as follows:

$$
S R_{t}=1-M M R_{t} \text {. }
$$

In case if you want to consider a longer period of time, you should calculate the probability of survival during the period $\mathrm{T}$ as follows:

$$
S R_{t}=\prod_{t=1}^{T} S R_{t} \text {. }
$$

Based on the submitted expressions, you can construct a formula the probability of default in year t provided "survival" in previous years, ie during the time period T. By its economic nature, it will be an indicator of the stability of the issuer of the securities, in our case - Portugal.

The formula is as follows:

$$
M R_{t}=M M R_{t} \cdot S R_{t-1} \text {. }
$$

If we consider the economic component represented by the expression, we can see that it accumulated all these formulas survival probability of survival, etc. MRt finding is important both for predicting default state, and in predicting defaults private commercial organizations. For example, if we take as a basis the formula probability of default in year $t$, then we can derive the following formula, which would reflect the probability of default for a specific period of time, as well as predictive formula to assess the situation in the economy, most businesses exposure to defaults.

For example, the probability of default in a specific time period will consist of all the formulas of the probability of default at a certain time $\mathrm{T}$, this period may be due to several years.

The cumulative probability of default CMR (cumulative mortality rate) for the period of time $\mathrm{T}$ years is represented as follows:

$$
C M R_{T}=\sum_{t=1}^{T} M R_{t}=1-\prod_{t=1}^{T} S R_{t} .
$$

Thus, the cumulative probability of default - is the probability that an issuer with the credit rating will default at any time between the date of issue of securities in circulation. In our case it is $t=0$ and the end of the calendar year T. In addition, the second part of the formula shows that the cumulative probability of default is calculated as add-ons to a single value. In this case, it means «survive" issuer or not, i.e. whether high probability of defaulting in a given period of time.

Another equally significant value represents the average probability of default AMR (average mortality rate), which suggests a certain dimension of the deflection angle of default component in the economy of a single value.

The higher it is, the greater the deviation from a single value, which indicates the overall risk of defaults in the economy. The indicator is calculated as follows:

$$
A M R=1-\sqrt[T]{1-C M R_{T}}
$$

Consequently, the study MMRt and CMR, the analysis of statistical data on these specifications Portuguese bonds, we can state the following pattern: the marginal probability of default increases over the first few years after bond issuance by Portugal. But then the situation has stabilized and the risk (probability of default) is reduced, but it is possible bursts «disbelief" in the Portuguese Securities. This may be due to several reasons. One of them consists in the fact that the borrower rating of Portugal is dominant in deciding whether to buy or 
sell securities. The probability of default to the most evident in the first 3 years. The second reason is that the Portuguese paper strongly influenced by the Securities Italy and Greece, which has a very negative impact on the overall market picture. In general, it should be noted that the risk of default is not threatened by the Portuguese Securities, on the contrary, there is a great likelihood of subsequent growth of bonds during 2014 on average by 3-4 \%, if we talk in relation to decadal bonds.

Thus, the risk of default and education situation in the economy, and the private enterprise can occur not only in European countries. Default risk and its definition - an important component of the assessment activities of country risk. However, we must focus on the fact that one and acceptable model of default risk assessment to date does not exist.

Recently, certain problems have been observed in Russian economy. In particular, the economic growth has strongly slowed down. Whereas the growth of the gross domestic product of the country was predicted to be about 4 percent for the year 2013 until recently, now it is a question of about 1-2\% of growth.

\begin{tabular}{|c|c|c|c|c|c|c|c|c|}
\hline & 2005 & 2006 & 2007 & 2008 & 2009 & 2010 & 2011 & 2012 \\
\hline Russia & 14.2 & 9.0 & 7.2 & 6.5 & 8.3 & 9.0 & 9.6 & 10.4 \\
\hline \multicolumn{9}{|c|}{$\begin{array}{l}\text { Countries - members } \\
\text { European Union }\end{array}$} \\
\hline Austria & 64.2 & 62.3 & 60.2 & 63.8 & 69.2 & 72.0 & 72.5 & 73.4 \\
\hline Belgium & 92.0 & 88.0 & 84.0 & 89.2 & 95.7 & 95.5 & 97.8 & 99.6 \\
\hline Bulgaria & 27.5 & 21.6 & 17.2 & 13.7 & 14.6 & 16.2 & 16.3 & 18.5 \\
\hline Hungary & 61.7 & 65.9 & 67.0 & 73.0 & 79.8 & 81.8 & 81.4 & 79.2 \\
\hline Germany & 68.5 & 68.0 & 65.2 & 66.8 & 74.5 & 82.4 & 80.4 & 81.9 \\
\hline Greece & 100.0 & 106.1 & 107.4 & 112.9 & 129.7 & 148.3 & 170.3 & 156.9 \\
\hline Denmark & 37.8 & 32.1 & 27.1 & 33.4 & 40.7 & 42.7 & 46.4 & 45.8 \\
\hline Ireland & 27.3 & 24.6 & 25.1 & 44.5 & 64.8 & 92.1 & 106.4 & 117.6 \\
\hline Spain & 43.2 & 39.7 & 36.3 & 40.2 & 53.9 & 61.5 & 69.3 & 84.2 \\
\hline Italy & 105.7 & 106.3 & 103.3 & 106.1 & 116.4 & 119.3 & 120.8 & 127.0 \\
\hline Cyprus & 69.4 & 64.7 & 58.8 & 48.9 & 58.5 & 61.3 & 71.1 & 85.8 \\
\hline Latvia & 12.5 & 10.7 & 9.0 & 19.8 & 36.9 & 44.4 & 41.9 & 40.7 \\
\hline Lithuania & 18.3 & 17.9 & 16.8 & 15.5 & 29.3 & 37.9 & 38.5 & 40.7 \\
\hline Luxembourg & 6.1 & 6.7 & 6.7 & 14.4 & 15.3 & 19.2 & 18.3 & 20.8 \\
\hline Malta & 68.0 & 62.5 & 60.7 & 60.9 & 66.4 & 67.4 & 70.3 & 72.1 \\
\hline Netherlands & 51.8 & 47.4 & 45.3 & 58.5 & 60.8 & 63.1 & 65.5 & 71.2 \\
\hline Poland & 47.1 & 47.7 & 45.0 & 47.1 & 50.9 & 54.8 & 56.2 & 55.6 \\
\hline Portugal & 67.7 & 69.4 & 68.4 & 71.7 & 83.7 & 94.0 & 108.3 & 123.6 \\
\hline Romania & 15.8 & 12.4 & 12.8 & 13.4 & 23.6 & 30.5 & 34.7 & 37.8 \\
\hline Slovakia & 34.2 & 30.5 & 29.6 & 27.9 & 35.6 & 41.0 & 43.3 & 52.1 \\
\hline Slovenia & 26.7 & 26.4 & 23.1 & 22.0 & 35.0 & 38.6 & 46.9 & 54.1 \\
\hline $\begin{array}{l}\text { United } \\
\text { Kingdom } \\
\end{array}$ & 42.2 & 43.3 & 44.2 & 52.7 & 67.8 & 79.4 & 85.5 & 90.0 \\
\hline (UK) & 41.7 & 39.6 & 35.2 & 33.9 & 43.5 & 48.6 & 49.0 & 53.0 \\
\hline Finland & 66.4 & 63.7 & 64.2 & 68.2 & 79.2 & 82.4 & 85.8 & 90.2 \\
\hline France & 43.7 & 35.5 & 32.9 & 28.9 & 35.3 & $\ldots$ & $\ldots$ & $\ldots$ \\
\hline Croatia & 28.4 & 28.3 & 27.9 & 28.7 & 34.2 & 37.8 & 40.8 & 45.8 \\
\hline $\begin{array}{l}\text { Czech } \\
\text { Republic }\end{array}$ & 50.4 & 45.3 & 40.2 & 38.8 & 42.6 & 39.4 & 38.4 & 38.2 \\
\hline
\end{tabular}

Table 2. Public debt as a percentage of gross domestic product Source: Federal service of state statistics

A default is an inability of the state to fulfill its obligations. And although Russia has some structural problems in the economy, a hole in the pension fund, a noticeable deficiency of the state budget, the country has some international reserves as well, which are estimated approximately at a level of 500 billion US dollars.

In practice, it means that even if a sharp recession in the collectability of taxes is observed in the country (for example, if a crisis arises in 2014), in case the price of oil and gas decreases by 2-2.5 times (as it already happened in 2008-2009), all the same Russia will remain solvent. At the worst, a small devaluation of the ruble may happen in 2014. But it will be of mild nature. An ordinary inhabitant will hardly notice its consequences.

The previous default happened in Russia in 1998. But then the state treasury was almost empty, there were no financial reserves and it was, consequently, impossible to service the debt.

Despite the significant improvement in the quality of debt management that occurred in the 2000s., In this work are still many shortcomings, some of which have already been mentioned. In general, still lack a strategic 
vision, which does not allow long-term strategy to develop multivariate. In addition, the rapidly changing conditions of development, objectively since 2005 makes adjust annually even medium-term policy.

And further debt management conditions will change. Even without major changes in the conditions of economic development in Russia related to the possible deterioration of the external economic situation, new methods will require active management of part of the debt market. Its share of the external debt rose to the top in 2014 to almost $80 \%$ against $17 \%$ in early 2000

In the past, actively discussed the idea of establishing a specialized debt management agency, which is in charge of operational issues have moved to debt management. Such specialized agencies or offices exist in many countries, where public debt consists solely of market-based instruments. However, due to the successful reduction of the external debt issue of agency debt dropped automatically.

However, currently significantly changed conditions of public debt management that allows us to speak about the need to revive the idea of a public debt management agency or office. Besides a significant increase in the share of market-based instruments in the structure of Russia's external debt, new approaches to the management of public debt and increasing demands of domestic debt market, as well as the explosive growth of corporate borrowing, much of which falls on the structures controlled by the state. These functions may perform specialized debt office or agency debt, which could in the longer term to bring an extra effect.

New opportunities for public debt management in open communication with the strengthening of the international position of the ruble. And here more freedom of action in debt policy could give the issue of Eurobonds denominated in rubles. In 2005-2006. already 16 Russian banks and companies have released such Eurobonds totaling 70.5 billion rubles. (almost $\$ 2.7$ billion). In addition, the ruble Eurobond loan put the EBRD, the German government agency KfW, the Norwegian export agency Eksportfinans. This is due, on the one hand, with the abolition of currency legislation in a July 1, 2006 all restrictions on the capital account for non-residents. On the other hand, the increasing demand of Russian and Western institutions for rubles. If such operations successfully succeed corporate structures, that is why they could not perform under certain conditions, the state, through a specialized body of public debt management, which would have followed the situation on the relevant market and engaged in placement and redemption of such debt instruments.

\section{Conclusion}

Special debt agency could engage in monitoring the regional and municipal debt and to assist the region in the management of regional debt. Relevance of this trend may increase in the near future due to the possible liberalization of state policies on regional external borrowing. The fact that after the 1998 crisis, some regions, published in foreign markets have experienced serious difficulties in servicing their obligations. After 1998, for the subjects of the Russian Federation were allowed only foreign loans to refinance old debt. However, new challenges of socio- economic development of the regions are forced to look for new sources of financing, including foreign ones.

Importance of establishing a special office or agency debt increases and due to the fact that Vnesheconombank - agent of the Government on management of external debt and foreign financial assets - will be converted and with Roseximbank and RBD forms a new Bank of the Russian Federation . Its main task will finance infrastructure and innovative projects, support for export and small businesses.

At the moment, the economy of Russia is stable. There are certain problems. In particular, the country's essential dependence on prices of raw material resources, a poorly diversified export, a lag of many branches of the economy behind the world's leaders. But it is impossible to say that the country risks encountering a new default in 2014. There is only a risk of a slight weakening of national currency and a small economic recession.

\section{Reference}

- Shapkin, Shapkin, 2012. Risk theory and modeling of risk /Publishing Dashkov and Co., Moscow, 880 p.

- Ustenko O. L., 2010. Theory of Economic risks. MAUP, Kiev.

- Vishnyakov, Radaev, 2008. General theory of risks: manual for the students at higher education institutions /Publishing Center "The Academy", Moscow, 368 p.

- Nadeem Walayat, 2010. Global Sovereign Debt Crisis, Country Bankruptcy Relative Risk of Default

- Eurostat, 2014. Euroindicators, http://ec.europa.eu/eurostat/euroindicators

- Federal service of state statistics, 2013. Russia and member-states of the European Union, http://www.gks.ru/bgd/regl/b13_65/IssWWW.exe/Stg//<extid>/<storagepath>::\%7C11-12.doc 